\title{
Assessing the Role of Leadership Mechanisms for Inter-agency Collaboration and Information Sharing Success in Indonesia
}

\author{
Djoko Sigit Sayogo
}

Author ORCID Nr: 0000-0002-7587-439X

University of Muhammadiyah Malang, Indonesia, dsayogo@umm.ac.id

Center for Technology in Government, University at Albany, SUNY, New York, USA

\section{J. Ramon Gil-Garcia}

Author ORCID Nr: 0000-0002-1033-4974

University at Albany, State University of New York, USA, jgil-garcia@albany.edu

Universidad de las Americas Puebla, Mexico

\section{Sri Budi Cantika Yuli}

Author ORCID Nr: 0000-0003-2870-9081

University of Muhammadiyah Malang, Indonesia, cantika@umm.ac.id

\begin{abstract}
Previous studies have identified leadership as an essential factor influencing interagency collaboration and information sharing in government settings. This study argues that some unique characteristics of inter-agency information sharing (IIS) initiatives across different jurisdictions and levels of government call for particular types of leadership. Specifically, this study uses data from in-depth interviews with fifteen public officials in Indonesia to better understand the role of leadership in inter-agency collaboration and information sharing initiatives. Findings from the interviews support two leadership mechanisms influencing IIS in Indonesia: executive involvement and exercise of formal authority, whereas the role of informal leaders seems to be less important in this case. It seems that in some developing countries such as Indonesia, informal leaders are not as influential to the success of IIS initiatives as formal ones, due to the influence of organizational culture.
\end{abstract}

Keywords: Inter-agency collaboration, information sharing, leadership, leadership mechanisms, informal leaders, executive involvement 
Acknowledgement: This work was partially supported by the Ministry of Higher Education of the Republic of Indonesia under Grant No. 015/SP2H/LT/MULTI/L7/2019. Any opinions, findings, and conclusions, or recommendations expressed in this material are those of the authors and do not necessarily reflect the views of the Ministry of Higher Education of the Republic of Indonesia.

\section{Introduction}

Advancements in Information and Communication Technologies (ICTs) facilitate the collective capabilities of agencies, private entities, and the general public to organize, interact and find solutions to overcome increasingly complex social challenges through sharing information (Johnston \& Hansen, 2011; Scholl \& Scholl, 2014). The capabilities for the sharing of information across government agencies are termed interagency information sharing or shortened as IIS (Dawes, 1996). IIS could be seen as the foundation of the government efforts to develop and execute public policies that are smart, efficient, and more responsive to current social problems (Scholl \& Scholl, 2014). The proponents argue that integrating and sharing information across agencies generate new technical, organizational, and political benefits for those involved (Dawes, 1996; Dawes, Cresswell, \& Pardo, 2009; Yang \& Maxwell, 2011). Even a developing country, such as Indonesia, has just recently enacted Presidential Decree no. 95 of 2018 to implement an electronic-based government system called SPBE (Sistem Pemerintahan Berbasis Elektronik) with an emphasis on the sharing of information across different government units and agencies.

An IIS project typically involves a significant number of participants from different government agencies and or across levels of government. For that reason, collaborative network settings are needed for efficient management of IIS (Dawes, 1996; Dawes et al., 2009). Collaborating in an IIS project can be challenging for government officials who were unaccustomed to work collaboratively across their respective agencies' boundaries (Dawes, 1996). Hence, leadership is seen as the appropriate mechanism to deal with the complexities of cross-boundary collaboration (Connelly, 2007). The main challenge of leadership in collaborations, such as IIS projects, is managing and balancing the interactions among various participants involved to mitigate or minimize the potential conflicts (Sullivan, Williams, \& Jeffares, 2012).

A particularly crucial challenge is understanding how the government officials must exercise the leadership functions to maintain the collaboration in IIS and keep it from collapsing (Gil-Garcia et al., 2007; Pardo et al., 2007). In an IIS project, leadership represents the social processes that signify the employment of leadership functions such as conflict resolution, decision making, and coordination (Pardo \& Tayi, 2007). In particular, leadership in IIS manifests through three mechanisms executive involvement, the exercise of formal authority, and informal leaders (Pardo et al in 2007). This paper explores the applicability of the three leadership mechanisms proposed by Pardo et al in 2007 to the case of a developing country: Indonesia. This paper contributes to a better understanding of the role of cultural contexts on the functioning of leadership mechanisms in IIS projects. This study conducted in-depth interviews with fifteen (15) public officials responsible for implementing IIS in the regency of Bojonegoro, Indonesia. The interview findings were used to assess the role of the cultural context in influencing the applicability of the three leadership mechanisms. 
This paper consists of 5 sections, including the preceding introduction. Section 2 highlights studies evaluating the influence of leadership mechanisms and activities on the performance of IIS initiatives. Section 3 presents a description of the research methodology. Section 4 presents our main results and discusses them considering previous research. Finally, Section 5 provides some concluding reamarks and suggests ideas for future research about this topic.

\section{Leadership Mechanisms and the Success of IIS Projects}

Pardo et al. 's (2007) and Gil-Garcia et al. 's (2007) characterize the leadership of IIS in terms of three mechanisms: executive involvement, exercising formal authority, and informal leaders. Involvement, support, and buy-in from top-level executive leaders is critical for the success of IT initiatives in the public sectors (Anderson, Bikson, Lewis, Moini, \& Straus, 2003; Bellamy, 2000; Eglene et al., 2007; Gil-García \& Pardo, 2005) as well as interagency information integration and sharing in the public sector (Dawes, 1996; Dawes \& Pardo, 2002; Eglene et al., 2007; Gil-Garcia et al., 2007; Landsbergen \& Wolken, 2001; Pardo et al., 2007). In contrast, the lack of support from executives could lead to the failure of inter-organizational information sharing (Zhang, Dawes, \& Sarkis, 2005). Dawes et al. (2009) further argue that the different roles of executive involvement are needed to sustain the collaboration in multi-agencies information sharing projects. At the initial stage, the participation of elected or career-based executives provides legitimating authority for the collaborative network (Dawes et al., 2009; Dawes \& Préfontaine, 2003), which is crucial because authority and power develop gradually in collaborative networks (Rethemeyer \& Hatmaker, 2008). Hence, executive involvement is necessary to provide formal legal authority (Dawes et al., 2009).

Subsequently, the roles of executive involvement changes throughout the implementation process of IIS projects. The executive is expected to change its functions to sustain collaboration across multiple implementation stages (Dawes et al., 2009). There are two leading roles that executive involvement is expected to fulfill during the implementation stage. The first role is to secure financial resources for the project. The participation of executives in negotiating bureaucratic processes for budget and financial purposes is vital to the implementation and success of IIS initiatives (Dawes et al., 2009; Eglene et al., 2007). Second, the executive facilitates coordination in collaborative networks. Pardo et al. (2007) and Gil-Garcia et al. (2007) assert that executives manage coordination in three ways: a) inciting the willingness of the key actors to participate, b) demonstrating respect for the autonomy of participating organizations, and c) supporting the action of informal leaders. Conclusively, the influence of executive involvement in the success of IIS projects occurs directly through the provision of support and resources and indirectly by supporting the roles of informal leaders and respect in the autonomy of participants when exercising formal authority.

The building of leadership in collaborative settings is likely to involve the interaction between structure (formal authority) and process (influence), which necessitate both informal and structurally formal leaders (Bryson, Crosby, \& Stone, 2006). The roles of informal leaders are no less critical than executive involvement in IIS projects (Dawes \& Pardo, 2002). Often, the participants need informal leaders because they cannot depend on direction from centralized formal leaders alone (Bryson et al., 2006). Informal leaders work at the operational level to get projects going (Gil-Garcia et al., 2007; Pardo et al., 2007). For instance, informal leaders are recognized as the ones who nurture 
trust-building among the participants (Gil-Garcia, Guler, Pardo, \& Burke, 2010), mitigate potential conflicts, and sustain coordination among the diverse participants (Gil-Garcia et al., 2007; Pardo et al., 2007). Both formal and informal leaders are needed to ensure effective collaboration (Bryson et al., 2006; Crosby \& Bryson, 2010).

Formal authority, control of critical resources, and discursive legitimacy are three significant powers that influence the dynamics of collaboration (Hardy \& Phillips, 1998) and signal the participant's dominance (Phillips, Lawrence, \& Hardy, 2000). In a collaboration, formal authority signifies the right to make decisions. The exercise of legal authority in IIS projects carries a leadership function (Dawes et al., 2009; Eglene et al., 2007). In particular, the exercises of formal authority affects the development of shared understanding and the mitigation of potential conflicts in a collaborative effort (Dawes et al., 2009; Eglene et al., 2007; Gil-Garcia et al., 2007; Pardo, Gil-Garcia, \& Burke, 2006; Pardo et al., 2007). Careful application of formal authority alleviates possible frictions among the participants, helps build trust, and provides a foundation for collaborative efforts in IIS (Pardo et al., 2006). Attentiveness in the exercise of formal authority fosters a willingness to participate in the implementation and, eventually, the success of IIS (Gil-Garcia et al., 2007; Pardo et al., 2007).

\section{Research Design and Methods}

The study conducted in-depth semi-structured interviews to identify and analyze the critical role of leadership mechanisms for the implementation of IIS at the local government level in Indonesia. In-depth interviews with 15 public managers and other public officials, ranging from the department of library and information services and the department of information and communication at the Regency of Bojonegoro, Indonesia, were conducted to gather the empirical data. The 15 interviewees were all the key players involved in implementing an IIS initiative at the local government and were selected based on their fundamental roles and functions in an IIS project in Bojonegoro. Among the different actors interviewed are: a) head of the department, b) manager of units within the department, and c) member of the regency IT boards (see table 1).

All interviews were recorded and transcribed as a whole to obtain rich empirical data. Interviews were transcribed and analyzed following an inductive logic and using grounded theory techniques (Strauss \& Corbin, 1997). The analytical processes conducted by the research team were iterative. Each team member analyzed the interview transcripts and then discussed them in the group resulting in inductive coding themes related to IIS critical leadership mechanisms. We conducted validation of the analysis results in two stages. First, the resulting constructs were contrasted with the previous studies originally used as the theoretical lens. Second, we also asked the respective interviewees to re-validate the resulting leadership mechanisms identified in the analysis of the interviews.

In addition, the interviewees ranked the importance of the leadership mechanisms according to their respective experiences during the IIS project. The interviewers rated the leadership mechanisms using the following guidance: "give ranking on the importance of the three leadership mechanisms in providing legitimating authority, securing financial resources, facilitating coordination, and mitigating conflicts during the IIS project." 
Table 1: Composition of the Interviewees

\begin{tabular}{|c|c|c|c|}
\hline No. & Department & Position & $\begin{array}{l}\text { Number of } \\
\text { Interviewees }\end{array}$ \\
\hline \multirow{3}{*}{1} & \multirow{3}{*}{ Department of Library and Information Service } & Head of Department & 1 \\
\hline & & Unit manager & 2 \\
\hline & & Staf & 4 \\
\hline 2 & Information and Techology Board & Head of Board & 1 \\
\hline \multirow{3}{*}{3} & \multirow{3}{*}{ Department of Information and Communication } & Head of Department & 1 \\
\hline & & Unit manager & 2 \\
\hline & & Staf & 1 \\
\hline 4 & Office of Legal \& Statutory Regulations & Unit manager & 1 \\
\hline \multirow[t]{2}{*}{5} & Department of Public Health & Unit manager & 2 \\
\hline & Total & & 15 \\
\hline
\end{tabular}

\section{Main Results and Discussion}

\subsection{Results}

This section describes the analysis of the interview results outlining the roles of leadership mechanisms in IIS implementation. One of the IIS cases and infrastructure in the regency of Bojonegoro is depicted in Figure 1.

Figure 1: IIS Infrastructure in the Department of Public Works \& Water Management

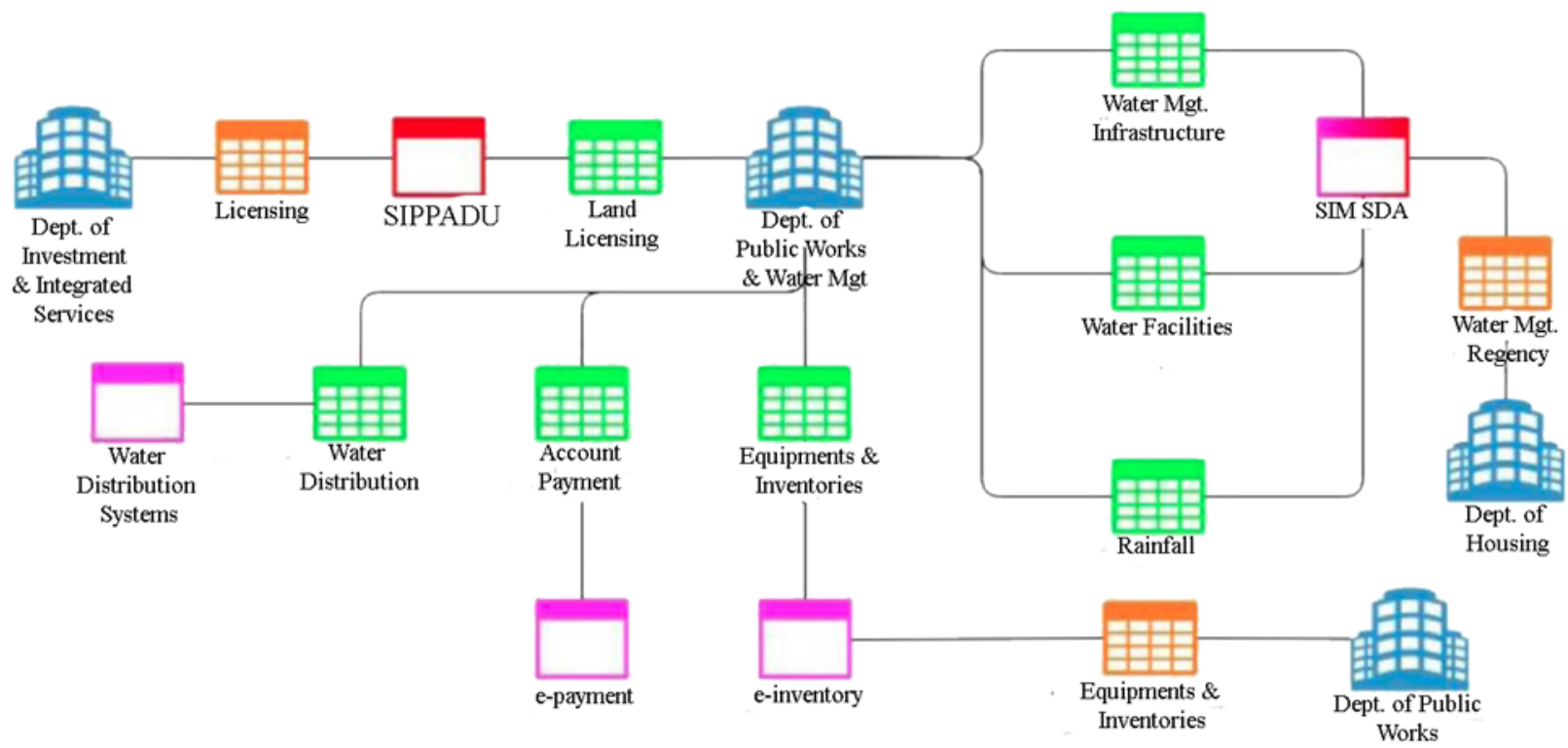

The interview results further substantiate that the roles of executive involvement are more prominent in developing countries such as Indonesia. The executives, especially top-level executives, are expected to delegate authority to their staff involved in the interagency information-sharing project. In the case of Indonesia, executives supervise the functioning of the project directly to avoid project 
failure. As stated by the head of the department from the department of communication and technology in Bojonegoro, "...when we invite all parties for a meeting, if the regent is not directly attending and supervising the meeting, they [other participants] will just leave and ignore the meeting, what's worse, [the project] will just become another pile of documents on their desk." Aside from that, consent from the executives is crucial for ensuring funding and the needed activities. According to the interviewee, the IT department will work on the application just because the executive asks them and approve the budget allocation and not because it is required. As asserted by one of the interviewees, "...the apps are not yet even needed, but it is for the sake of budget absorption, the executive said to do it then it has to be done..."

The interview results further demonstrate that executive support for informal leaders is not substantial in the case of Indonesia. The influence of formal authority from executives is more prominent than the role of informal leaders. As stated by the head of the department of communication and technology in Bojonegoro, "...No, from experiences.... it all needs the commitment from the executives, both the Regent and the head of the departments...if they say so...it will get done". Informal leaders are often labeled as a possible source of conflict, sowing discord between the staff and the executives. Thus, top-level executives in Indonesia use informal control mechanisms as a more personal approach in dealing with the employees instead of encouraging the emergence of informal leaders.

Our interview results also indicate the importance of the exercise of formal authority for interagency collaboration in Indonesia. However, the way it is exercised is different from other contexts. The decision tree is strictly hierarchical in Indonesia from the upper echelon down to the subordinates in the hierarchy. As a result, the exercise of formal authority then means simply conveying the will of the top-level executives without any alterations because, as found from the interviews, highlevel executives might micro-manage the collaboration process. Thus, power contestation in the interagency collaboration project will not materialize at the participant level. Although the interview findings indicate the possibility of conflicts occuring at the technical level among the participants. However, such conflict was often handled using a personal approach, either from the head of the department involved or by inviting religious clerics to solve the conflicts. As stated by one of the interviewees..."...it is, after all, a social relationship, differences (conflict) could happen...thus someone, either the head of the department or the regent or even religious clerics must bridge the differences...".

\subsection{Discussion and Implications}

The premise of this paper is to describe and critically analyze the impact of leadership mechanisms - executive involvement, exercise of formal authority, and informal leaders - on the successful implementation of IIS in the Bojonegoro regency, Indonesia. This study evaluated the impact of leadership mechanisms and activities in a less well-understood area of IIS across different jurisdictions and levels of government through a qualitative approach. Findings from the thematic analysis demonstrate that only two of the three leadership mechanisms identified by Pardo et al. Were found in the interviews as substantial, affecting IIS success in a developing country. 
Our findings provide clear support of the influence of bureaucratic leadership, in the form of executive involvement, in shaping the success of IIS projects. The question and hypothesis about the embeddedness of leadership in bureaucratic environments and its effect on the success of information sharing were raised by Eglene et al. (2007). Pardo et al. (2007) and Gil-Garcia et al. (2007) further enriched the idea of bureaucratic embeddedness of leadership in IIS initiatives. The involvement and participation of top-level executives have long been regarded as one of the primary reasons for IT (information technology) project success in an organization, including profit-oriented firms (Jarvenpaa \& Ives, 1991) and the health sector (Kaplan \& Harris-Salamone, 2009).

Our findings enriched this argument by exposing the critical role of executive involvement in ICTs (information \& communication technologies) projects across different jurisdictions and levels of government. Our findings further supported and confirmed the propositions of Pardo et al. (2007) and Gil-Garcia et al. (2007) concerning, in particular, the direct influence of executive involvement in the success of IIS. Executive involvement significantly influences IIS success directly through the provision of funding, provision of authority, and in the case of a developing country, direct supervision to the collaborative processes within the IIS initiative. The need for direct supervision from the top-level executives presumably stemmed from the long history of rigid bureaucratic and autocratic administration in Indonesia. After decades of authoritarian culture, leadership in Indonesia tends to be autocratic (Efferin \& Hopper, 2007; Van de Vliert, 2006). It is possible to argue that the staff involved in interagency information sharing projects perceived the involvement of top-level executives as a form of guarantee to absolve the team from the blame should the project fail.

Overall, our findings strongly highlighted the importance of executive involvement. Thus, they demonstrate the bureaucracy's effects on the success of inter-organizational information sharing in the case of Indonesia. Executive involvement ensures access to resources directly needed for the project and patronage (Eglene et al., 2007). Executive involvement is even more central in the case of a developing country such as Indonesia. Executive involvement manifests through the provision of legitimacy for those involved in the interagency collaboration and direct involvement in supervising the progress of the IIS collaboration. Mainly because the personal considers the direct involvement of top-level executives as a safe harbor to shelter them from blame should the project fail. Based on our findings, this study purports the following proposition:

Proposition\#1: Bureaucratic embeddedness manifested in the form of executive involvement is crucial to a successful implementation of IIS

In addition, interview results indicate the non-existent role of informal leaders in the case of Indonesia. Previous studies have ascertained the significant role of informal leaders for the success of a collaborative project [see, for instance: Balkundi \& Harrison (2006); Balkundi \& Kilduff (2006); Huxham \& Vangen (2000); Crosby \& Bryson (2006) and Bryson et al. (2006)]. The same argument also applies to inter-organizational information sharing and integration projects [see Dawes et al., 2009; Gil-Garcia et al., 2010, 2007; Pardo et al., 2007; Zheng et al., 2009, and others]. Informal leaders are the crucial movers and shakers of the project at the operational level to perform coordinating activities such as nurturing the development of trust or mitigating the potential of conflicts (GilGarcia, Guler, Pardo, \& Burke, 2010; Gil-Garcia et al., 2007; Pardo et al., 2007). All of these studies mainly focus on cases in developed countries. On the contrary, the crucial role of informal leaders 
for the success of interagency information sharing is less apparent in the case of Indonesia, which could be smilar to other developing countries.

Additionally, informal leaders need support and sponsorship from formal leaders for efficient functioning because even if informal leaders often have a strong influence, they have less formal authority. Support from executives provides informal leaders with authority to act in the collaboration (Eglene et al., 2007), which is particularly important because formal authority is often developed gradually in networks (Rethemeyer \& Hatmaker, 2008). On the other hand, the interviews de-emphasize the role of informal leaders in developing countries such as Indonesia. Informal leaders are often labeled as a possible source of conflict, sowing discord between the staff and the executives. Thus, executives in Indonesia tend to discourage the emergence of informal leaders for the fear that informal leaders will incite hostile attitudes and resistance from staff (Efferin \& Hopper, 2007).

The findings presumably stem from the autocratic culture in Indonesia (Efferin \& Hopper, 2007; Van de Vliert, 2006). Thus, top-level executives in Indonesia tend to retained the majority of the control and revert to use informal control mechanisms in the forms of a more personal approach in dealing with the employees, instead of encouraging the emergence of informal leaders. They use a more personalized way to convey expectations and objectives, establish job descriptions, supervise staff, delineate roles for each staff, and decide rewards and punishments (Efferin \& Hartono, 2015). Based on the justifications mentioned above, this study proposes the following:

Proposition\#2: A hierarchical, bureaucratic environment diminishes the importance of informal leaders to a successful implementation of IIS

Finally, the findings from the interviews indicate the importance of the exercise of formal authority to the success of the IIS project. Formal authority implies power and dominance in the collaboration (Phillips et al., 2000) because it signifies the right to decide (Hardy \& Phillips, 1998). An individual who may occupy a position of considerable formal authority in their respective organization may not feel at ease of sharing power with other participants in the IIS project (Alexander, Comfort, Weiner, \& Bogue, 2001). Power contestation among participants could lead to conflicts and, subsequently, the failure of the IIS project. Given the autocratic leadership culture in Indonesia, plausibly, the executives perceived that misuse of formal authority could lead to power contestation and conflicts. To maintain complete control over the project, the executive tends not to delegate formal authority to the participants to avoid conflict. This observation based on anecdotal evidence warrants future research to further understand the influence of autocratic versus democratic leadership on power contestation in ICT projects.

\section{Concluding Remarks}

The role of leadership in inter-organizational collaborations has been a contested issue for a long time. Although leadership has been proposed as one of the best mechanisms to deal with the complexities in collaborations, the conceptualization of leadership and its main mechanisms of influence in these inter-organizational contexts are not yet clear (Connelly, 2007). In fact, some studies define leadership in collaborations as the "mechanisms that make things happen" (Huxham \& Vangen, 
2000b; Müller-Seitz, 2012). Yet, collaborating in the context of interagency information sharing (IIS) possesses distinctive characteristics. We argue in this study that the unique features of IIS call for a type of leadership that is rarely discussed in the collaborative leadership literature.

Our findings confirmed the roles of two out of three inter-related leadership mechanisms proposed by Pardo et al. (2007) as critical predictors of IIS success: executive involvement and exercise of formal authority. Our findings also support the importance of bureaucratic embeddedness of leadership in IIS initiatives, in the form of executive involvement, in shaping the success of IIS projects directly. Executive involvement in developing countries such as Indonesia is vital in providing legitimate authority to act and representing direct involvement and supervision of specific actions in an interagency collaboration and information sharing initiative. Likewise, affected by the autocratic culture, government executives also tend not to delegate formal authority to avoid creating power contestations and conflicts among participants in IIS initiatives.

The results of this study have important implications for practice and highlight several potential avenues for future research. First, the effect of executive involvement on the success of IIS is critical. The project manager could use this knowledge to better plan the timing and amount of executive involvement needed to support IIS projects. Our findings also indicate that patronage from executives is a crucial component in curbing the negative behavior of participants when exercising their formal authority. Consequently, obtaining support from executives when the project is faced with conflict arising from misuse of formal authority would increase the probabilities of success in ISS projects. Finally, our sample consists of 15 interviewees involved in implementing IIS at the local government level. Although the 15 interviewees were selected on their fundamental roles and functions in the IIS project and adding more interviews would simply increase repetitive responses (since theoretical saturation was reached), some might argue for a larger sample. Hence, future research could test the robustness of our findings by analyzing other cases using a larger number of interviews or administering quantitative surveys.

\section{References}

Alexander, J. A., Comfort, M. E., Weiner, B. J., \& Bogue, R. (2001). Leadership in Collaborative Community Health Partnerships. Nonprofit Management and Leadership, 12(2), 159-175. http://doi.org/10.1002/nml.12203

Anderson, R. H., Bikson, T. K., Lewis, R., Moini, J. S., \& Straus, S. G. (2003). Effective Use of Information Technology. RAND Corporation. Retrieved from http://www.rand.org/cgi-bin/Abstracts/e-getabbydoc.pl?MR-1704-BSA

Balkundi, P., \& Harrison, D. A. (2006). Ties, Leaders, And Time In Teams: Strong Inference About Network Structure's Effects On Team Viability And Performance. Academy of Management Journal, 49(1), 49-68. http:// doi.org/10.5465/AMJ.2006.20785500

Balkundi, P., \& Kilduff, M. (2006). The ties that lead: A social network approach to leadership. The Leadership Quarterly, 17(4), 419-439. http:// doi.org/10.1016/j.leaqua.2006.01.001

Bellamy, C. (2000). The politics of public information systems. In D. G. Garson (Ed.), Handbook of Public Information Systems (Vol. 77, pp. 85-98). Marcel Dekker, Inc. Retrieved from 
https:/ / books.google.com/books?hl=en\&lr=\&id=8aXp031tODMC\&oi=fnd\&pg=PA85\&dq=The+Politics+of+Public+Information+Systems\&ots=YfcVXAgEpp\&sig=lLbqlkPxdKE4pQekCsnvVdzldz8

Bryson, J. M., Crosby, B. C., \& Stone, M. M. (2006). The Design and Implementation of Cross-Sector Collaborations: Propositions from the Literature. Public Administration Review, 66, 44-55.

Connelly, D. R. (2007). Leadership in the Collaborative Interorganizational Domain. International Journal of Public Administration, 30(11), 1231-1262. http:// doi.org/10.1080/01900690701230150

Crosby, B. C., \& Bryson, J. M. (2010). Integrative leadership and the creation and maintenance of cross-sector collaborations. The Leadership Quarterly, 21(2), 211-230. http://doi.org/10.1016/j.leaqua.2010.01.003

Dawes, S. S. (1996). Interagency information sharing: Expected benefits, manageable risks. Journal of Policy Analysis and Management, 15(3), 377-394.

Dawes, S. S., Cresswell, A. M., \& Pardo, T. A. (2009). From "need to know" to "need to share": Tangled problems, information boundaries, and the building of public sector knowledge networks. Public Administration Review, 69(3), 392-402.

Dawes, S. S., \& Pardo, T. A. (2002). Building Collaborative Digital Government Systems. In W. J. M. Jr \& A. K. Elmagarmid (Eds.), Advances in Digital Government (pp. 259-273). Springer US. Retrieved from http://link.springer.com/chapter/10.1007/0-306-47374-7_16

Dawes, S. S., \& Préfontaine, L. (2003). Delivering government services. Communications of the ACM, 46(1), 41.

Eglene, O., Dawes, S. S., \& Schneider, C. A. (2007). Authority and leadership patterns in public sector knowledge networks. The American Review of Public Administration, 37(1), 91-113.

Efferin, S., \& Hopper, T. (2007). Management control, culture and ethnicity in a Chinese Indonesian company. Accounting, Organizations and Society, 32(3), 223-262.

Efferin, S., \& Hartono, M. S. (2015). Management control and leadership styles in family business: An Indonesian case study. Journal of Accounting \& Organizational Change, 11(1), 130-159.

Gil-Garcia, J. R., Guler, A., Pardo, T., \& Burke, G. B. (2010). Trust in government cross-boundary information sharing initiatives: Identifying the determinants. In System Sciences (HICSS), 2010 43rd Hawaii International Conference on (pp. 1-10). IEEE. Retrieved from http://ieeexplore.ieee.org/xpls/abs_all.jsp?arnumber $=5428341$

Gil-García, J. R., \& Pardo, T. A. (2005). E-government success factors: Mapping practical tools to theoretical foundations. Government Information Quarterly, 22(2), 187-216.

http://doi.org/10.1016/j.giq.2005.02.001

Gil-Garcia, J. R., Pardo, T. A., \& Burke, G. B. (2007). Government leadership in multi-sector IT-enabled networks: Lessons from the response to the West Nile Virus outbreak. In Workshop 4: Leading in a MultiSector Environment. Retrieved from http://ctg.albany.edu/publications/journals/government_leadership/government_leadership.pdf

Hardy, C., \& Phillips, N. (1998). Strategies of Engagement: Lessons from the Critical Examination of Collaboration and Conflict in an Interorganizational Domain. Organization Science, 9(2), 217-230. 
Huxham, C., \& Vangen, S. (2000a). Leadership In The Shaping And Implementation Of Collaboration Agendas: How Things Happen In A (Not Quite) Joined-Up World. Academy of Management Journal, 43(6), 1159-1175. http:// doi.org/10.2307/1556343

Huxham, C., \& Vangen, S. (2000b). Leadership In The Shaping And Implementation Of Collaboration Agendas: How Things Happen In A (Not Quite) Joined-Up World. Academy of Management Journal, 43(6), 1159-1175. http://doi.org/10.2307/1556343

Jarvenpaa, S. L., \& Ives, B. (1991). Executive Involvement and Participation in the Management of Information Technology. MIS Quarterly, 15(2), 205-227. http:// doi.org/10.2307/249382

Johnston, E. W., \& Hansen. (2011). Design lessons for smart governance infrastructures. In A. P. Balutis, D. Ink, \& T. F. Buss (Eds.), Transforming American Governance: Rebooting the Public Square. Routledge.

Kaplan, B., \& Harris-Salamone, K. D. (2009). Health IT Success and Failure: Recommendations from Literature and an AMIA Workshop. Journal of the American Medical Informatics Association, 16(3), 291-299. http://doi.org/10.1197/jamia.M2997

Landsbergen, D., \& Wolken, G. (2001). Realizing the Promise: Government Information Systems and the Fourth Generation of Information Technology. Public Administration Review, 61(2), 206-220.

Müller-Seitz, G. (2012). Leadership in Interorganizational Networks: A Literature Review and Suggestions for Future Research. International Journal of Management Reviews, 14(4), 428-443. http://doi.org/10.1111/j.1468-2370.2011.00324.x

Pardo, T. A., \& Burke, G. B. (2008). Improving Government Interoperability: A capability framework for government managers. Working Paper, Center for Technology in Government, University at Albany. Research Foundation of State University of New York. Retrieved from http://ctg.albany.edu/publications/reports/improving_government_interoperability

Pardo, T. A., Gil-Garcia, J. R., \& Burke, G. B. (2007). Informal leadership and networks: Lessons from the response to the West Nile Virus outbreak. In Expanding the Knowledge Economy: Issues, Applications, Case Studies. IOS Press, Amsterdam. Retrieved from https://ctg.albany.edu/publications/journals/e2007_informal_leadership/e-2007_informal_leadership.pdf

Pardo, T. A., \& Tayi, G. K. (2007). Interorganizational information integration: A key enabler for digital government. Government Information Quarterly, 24(4), 691-715.

Phillips, N., Lawrence, T. B., \& Hardy, C. (2000). Inter-organizational Collaboration and the Dynamics of Institutional Fields. Journal of Management Studies, 37(1), no-no. http://doi.org/10.1111/14676486.00171

Rethemeyer, R. K., \& Hatmaker, D. M. (2008). Network Management Reconsidered: An Inquiry into Management of Network Structures in Public Sector Service Provision. Journal of Public Administration Research and Theory, 18(4), 617-646. http://doi.org/10.1093/jopart/mum027

Scholl, H. J., \& Scholl, M. J. (2014). Smart Governance: A Roadmap for Research and Practice. In the iConference. Illinois: IDEALS.

Sullivan, H., Williams, P., \& Jeffares, S. (2012). Leadership for Collaboration. Public Management Review, 14(1), 41-66. http://doi.org/10.1080/14719037.2011.589617 
Strauss, A., \& Corbin, J. M. (1997). Grounded Theory in Practice. SAGE.

Van de Vliert, E. (2006). Autocratic leadership around the globe: Do climate and wealth drive leadership culture?. Journal of Cross-Cultural Psychology, 37(1), 42-59.

Yang, T.-M., \& Maxwell, T. A. (2011). Information-sharing in public organizations: A literature review of interpersonal, intra-organizational and inter-organizational success factors. Government Information Quarterly, 28(2), 164-175. http://doi.org/10.1016/j.giq.2010.06.008

Zhang, J., Dawes, S. S., \& Sarkis, J. (2005). Exploring stakeholders' expectations of the benefits and barriers of e-government knowledge sharing. Journal of Enterprise Information Management, 18(5), 548-567. http://doi.org/10.1108/17410390510624007

Zheng, L., Dawes, S., \& Pardo, T. A. (2009). Leadership Behaviors in Cross-boundary Information Sharing and Integration: Comparing the US and China. In Proceedings of the 3rd International Conference on Theory and Practice of Electronic Governance (pp. 43-50). New York, NY, USA: ACM. http://doi.org/10.1145/1693042.1693052

\section{About the Author}

\section{Djoko Sigit Sayogo}

Djoko is an assistant professor in the Department of Economics and Business at the University of Muhammadiyah at Malang (UMM). Additionally, he is the Vice Director of Research at UMM. His research interests focus on the application of information technology for public policy, management, and economic development. Djoko also serves as Research Fellow at the Center for Technology in Government, University at Albany, State University of New York, New York, USA.

\section{J. Ramon Gil-Garcia}

J. Ramon Gil-Garcia is the Director of the Center for Technology in Government and an Associate Professor of Public Administration and Policy at the University at Albany, State University of New York. Dr. Gil-Garcia is a member of the Mexican National System of Researchers and of the Mexican Academy of Sciences. In 2009, he was considered the most prolific author in the field of digital government research worldwide, and in 2013 he was selected for the Research Award, which is "the highest distinction given annually by the Mexican Academy of Sciences to outstanding young researchers." More recently, Dr. Gil-Garcia was named "One of the World's 100 Most Influential People in Digital Government" in 2018 and 2019 by Apolitical, which is a nonprofit organization based in London, United Kingdom. In 2021, he was one of the recipients of the two inaugural Digital Government Society (DGS) Fellows Awards. Currently, he is also a professor of the Business School at Universidad de las Americas Puebla in Mexico, a Faculty Affiliate at the National Center for Digital Government, University of Massachusetts Amherst and an Affiliated Faculty member of the Information Science Doctorate Program at the College of Emergency Management, Homeland Security and Cybersecurity, University at Albany. Dr. Gil-Garcia is the author or co-author of articles in numerous prestigious international journals and some of his publications are among the most cited in the field of digital government research worldwide. His research interests include collaborative digital government, inter-organizational collaboration and information integration, smart cities and smart governments, data and data analytics for decision making, artificial intelligence in government, adoption and implementation of emergent technologies, and digital divide policies. 


\section{Sri Budi Cantika Yuli}

Yuli is an assistant professor at the Department of Economics and Business at the University of Muhammadiyah at Malang (UMM). Her research interests focus on Islamic organization behavior and theory and management. She actively participates in economic conferences both in Indonesia and abroad. 